\title{
European Union approach in monitoring drinking water quality: Emergency case management and risk analysis for the protection of public health
}

\section{İçme suyu kalitesinin izlenmesinde Avrupa Birliği yaklașımı: Halk sağlığının korunması için acil durum yönetimi ve risk analizi}

\author{
Dilek DiKMEN ${ }^{1}$, Hasan IRMAK ${ }^{1}$
}

\begin{abstract}
EU twinning light project entittled "Emergency case management and risk analysis in drinking water for the protection of public health" was implemented within the frame of Support Activities to Strengthen the European Integration Process SEI-2009 programming by the Ministry of Health, Public Health Institution of Turkey, Consumer and Employee Safety Vice-Presidency, Environmental Health Department with the cooperation of Italy - the Istituto Superiore di Sanita, (Italian National Institute of Health - ISS), Inland Water Hygiene Section, Environmental Primary Prevention Department for six months period between January 2013 and June 2013. The aim of the Project was to strengthen the Ministry of Health, Public Health Institution of Turkey in the field of drinking water by means of building institutional capacity for risk assessment, early warning and management of emergency cases in line with EU Drinking Water Legislation $(98 / 83 / \mathrm{EC})$. The project had four mandatory results. Result 1 was to improve the risk assessment capacity of Ministry of Health - Public Health Institution of Turkey in drinking water. Result 2 was to develop methodologies for identifying contamination in drinking water. Result 3 was to improve the early warning capacity of the Ministry of Health - Public Health Institution of Turkey in drinking water. Result 4 was to improve the emergency case management capacity of the Ministry of Health - Public Health Institution of
\end{abstract}

\section{ÖZET \\ $A B$ Entegrasyon Sürecinin Desteklenmesi} Faaliyetleri - SEI 2009 programlaması kapsamında "İçme Sularında Halk Sağlığının Korunması için Acil Durum Yönetimi ve Risk Analizi” başlıklı kısa süreli eșleștirme projesi Sağlık Bakanlığı Türkiye Halk Sağlığı Kurumu (Çevre Sağlığı Daire Başkanlığı) tarafından İtalya - the Istituto Superiore di Sanita, (Italya Ulusal Sağlık Enstitüsü - ISS), İç Suların Hijyeni Birimi, Çevre Birincil Önleme Bölümü işbirliğinde Ocak 2013 ile Haziran 2013 tarihleri arasında altı ay süre ile yürütülmüștür. Projenin amacı içme suyu alanında risk değerlendirmesinin, erken uyarı ve acil durum yönetiminin $A B$ içme suyu mevzuatı (98/83/EC) ile aynı doğrultuda gerçekleștirilmesi için kurumsal kapasitenin olușturulmasında Sağlık Bakanlığı Türkiye Halk Sağlığı Kurumunun güçlendirilmesidir. Proje dört zorunlu hedeften olușmuștur. 1. hedef: içme suyunda Sağlık Bakanlığı Türkiye Halk Sağlığı Kurumunun risk değerlendirme kapasitesinin geliștirilmesidir. 2. hedef: içme suyunda kontaminasyonların tanımlanmasına yönelik metodolojilerin olușturulması; 3. hedef: Sağlık Bakanlığı Türkiye Halk Sağlığı Kurumunun içme suyundaki erken uyarı kapasitesinin geliștirilmesi ve 4 . hedef: Sağlık Bakanlığı Türkiye Halk Sağı̆ğı Kurumunun içme suyundaki acil durum yönetim kapasitesinin

'The Ministry of Health, Public Health Institution of Turkey, Ankara, Turkey

İletişim/Corresponding Author: Hasan IRMAK
$\begin{array}{ccc}\text { Adnan Saygun Cad. No: } 55 \text { E Blok Park Girişi No: } 7 \text { Sihhiye 06420 Ankara - Türkiye } & \text { Geliş Tarihi / Received : 28.04.2016 } \\ \text { Tel : +90532666 } 1038 & \text { E-posta/E-mail : hsn.irmak@gmail.com } & \text { Kabul Tarihi / Accepted : 14.06.2016 }\end{array}$

DOI ID : 10.5505/TurkHijyen.2016.83436

Dikmen D, Irmak H. European Union approach in monitoring drinking water quality: Emergency case management and risk analysis for the protection of public health Turk Hij Den Biyol Derg, 2016; 73(3): 271-278 
Turkey in drinking water. The all project mandatory results were successfully reached. Besides extensive trainings and workshops, four guidance documents concerning the instructions for decision-making following non-compliance results in drinking water monitoring, identification of contamination, early warning and emergency case/crisis management in drinking water were prepared, published and distributed. The technical and institutional capacity of the Ministry of Health in the field of drinking water were improved both at the central level and provincial level involving 81 provinces.

Key Words: drinking water, public health, 98/83/ EC directive, twinning project, emergency case management, risk analysis geliștirilmesidir. Projenin tüm zorunlu hedeflerine başarıyla ulaşılmıștır. Kapsamlı eğitim ve çalıștayların yanı sıra içme sularının izlenmesi esnasında karșılașılan uygunsuzluk durumlarında karar verme süreci, içme sularında kirliliğin belirlenmesi, erken uyarı, acil durumlar ve kriz yönetimi konularında dört rehber kitap hazırlanmıș, bastırılmış ve dağıtılmıștır. Sağlık Bakanlığının teknik ve kurumsal kapasitesi hem merkezi düzeyde hem de 81 il düzeyinde olmak üzere güçlendirilmiștir.

Anahtar Kelimeler: içme suyu, halk sağlığı, 98/83/EC direktifi, eșleștirme projesi, acil durum yönetimi, risk analizi

\section{INTRODUCTION}

High quality, safe and sufficient drinking water is essential for our daily life, for drinking, food preparation and for many other purposes, such as washing, cleaning, hygiene or watering our plants.

The European Union has a history of over 30 years of drinking water policy. This policy ensures that water intended for human consumption can be consumed safely on a life-long basis, and this represents a high level of health protection. The main pillars of the policy are to: ensure that drinking water quality is controlled through standards based on the latest scientific evidence; secure an efficient and effective monitoring, assessment and enforcement of drinking water quality; provide the consumers with adequate, timely and appropriately information; contribute to the broader EU water and health policy (1).

COUNCIL DIRECTIVE 98/83/EC OF 3 NOVEMBER 1998 ON THE QUALITY OF WATER INTENDED FOR HUMAN CONSUMPTION

The Drinking Water Directive, Council Directive 98/83/EC of 3 November 1998 on the quality of water intended for human consumption concerns the quality of water intended for human consumption. Its objective is to protect human health from adverse effects of any contamination of water intended for human consumption by ensuring that it is wholesome and clean (2).

The Drinking Water Directive applies to; all distribution systems serving more than 50 people or supplying more than 10 cubic meter per day, but also distribution systems serving less than 50 people/supplying less than 10 cubic meter per day if the water is supplied as part of an economic activity; drinking water from tankers; drinking water in bottles or containers; water used in the foodprocessing industry, unless the competent national authorities are satisfied that the quality of the water cannot affect the wholesomeness of the foodstuff in its finished form.

The Drinking Water Directive doesn't apply to; natural mineral waters recognised as such by the competent national authorities, in accordance with Council Directive 80/777/EEC of 15 July 1980 
on the approximation of the laws of the Member States relating to the exploitation and marketing of natural mineral waters and repealed by Directive 2009/54/EC of 18 June 2009 on the exploitation and marketing of natural mineral waters; and waters which are medicinal products within the meaning of Council Directive 65/65/EEC of 26 January 1965 on the approximation of provisions laid down by law, regulation or administrative action relating to medicinal products and repealed by Directive 2001/83/EC of 6 November 2001 on the Community code relating to medicinal products for human use.

The Directive laid down the essential quality standards at EU level. A total of 48 microbiological, chemical and indicator parameters must be monitored and tested regularly. In general, World Health Organization's guidelines for drinking water and the opinion of the Commission's Scientific Advisory Committee are used as the scientific basis for the quality standards in the drinking water.

When translating the Drinking Water Directive into their own national legislation, Member States of the European Union can include additional requirements e.g. regulate additional substances that are relevant within their territory or set higher standards. Member States are not allowed, nevertheless, to set lower standards as the level of protection of human health should be the same within the whole European Union.

Member States may, for a limited time depart from chemical quality standards specified in the Directive (Annex I). This process is called derogation. Derogations can be granted, provided it does not constitute a potential danger to human health and provided that the supply of water intended for human consumption in the area concerned cannot be maintained by any other reasonable means.

The Directive also requires providing regular information to consumers. In addition, drinking water quality has to be reported to the European Commission every three years. The scope of reporting is set out in the Directive. The Commission assesses the results of water quality monitoring against the standards in the Drinking Water Directive and after each reporting cycle produces a synthesis report, which summarizes the quality of drinking water and its improvement at a European level. Further principles laid in the Directive are; Planning; Regulation (obligations of the Member States and the Commission); Monitoring; Information and Reporting (3).

THE COMMISSION DIRECTIVE 2015/1787 OF OCTOBER 2015 AMENDING ANNEX II AND III TO COUNCIL DIRECTIVE 98/83/EC ON THE QUALITY OF WATER INTENDED FOR HUMAN CONSUMPTION

The Commission performed in 2014 a public consultation on the quality of drinking water in the EU in order to assess the need for improvements on EU drinking water legislation. This consultation led to revision of Council Directive 98/83/EC of 3 November 1998 on the quality of water intended for human consumption (Drinking Water Directive) (4). The Drinking Water Committee gave a positive opinion to adapt the Annexes to scientific and technical progress. The amendments will give an opportunity to monitor drinking water parameters at more appropriate frequencies. The new Annex II provides an option to perform the drinking water monitoring in around 100,000 water supply zones in Europe in a more flexible way, provided a risk assessment is performed ensuring full protection of public health. It follows the principle of 'hazard analysis and critical control point' (HACCP) used already in food legislation, and the water safety plan approach laid down in the WHO Guidelines for Drinking Water Quality. These amendments will allow a better and more problem-oriented monitoring of small water supplies. The new monitoring and control system allows to reduce unnecessary analyses and to concentrate on those controls that matter (4). 
The Directive 2015/1787 amending Annex II and III to Council Directive $98 / 83 /$ EC on the quality of water intended for human consumption was adopted by the Commission on 6th October 2015 and entered into force on 27th October 2015 (4, 5). The Member States have 24 months to transpose the provisions of this new legislation into their national legislation (4, $6)$.

The Member States can now decide, on the basis of a risk assesssment which parameter to monitor given that some drinking water supply zones do not pose any risk for finding hazardous substances. They can also choose to increase or reduce the frequency of sampling in water supply zone as well as to extend the list of substances to monitor in case of public health concerns. The flexibility in the monitoring of parameters and the frequency of sampling is to ensure protection of public health (6).

Concerning radioactive substances in drinking water, in 2013 a Council Directive 2013/51/EURATOM was adopted, to be transposed by 28 November 2015 , superseding the radioactivity requirements in Directive 98/83/EC $(4,7)$.

\section{TURKISH LEGISLATION}

The Council Directive 98/83/EC of 3 November 1998 has been fully transposed to the Turkish legislation by the Ministry of Health with the By-law on Water Intended for Human Consumption, which was published in the Official Gazette No.25730, dated 17 February 2005. The By-law was amended in 2009, 2013 and 2014. The amendments were published in the Official Gazettes 31.7.2009 dated 27305 numbered, 7.03.2013 dated 28580 numbered and 11.04.2014 dated 28969 numbered (8).

The Ministry of Health, Public Health Institution of Turkey is responsible for the enforcement and implementation of the provisions of the By-law.

In the administrative system of supplying safe drinking water, various institutions have different functions and responsibilities. The Ministry of Health, Public Health Institution of Turkey is responsible for determining the quality standards of drinking water, monitoring of these standards and making legislation concerning these areas. The other related institutions are the Ministry of Environment and Urbanization, the Ministry of Forestry and Water Affairs, Municipalities and Special Provincial Administrations, the General Directorate of State Hydraulic Works, Bank of Provinces and the Ministry of Food, Agriculture and Animal Husbandry (9).

\section{TWINNING}

Twinning is a European Union instrument for institutional cooperation between Public Administrations of EU Member States and of beneficiary countries. It was originally designed in 1998 to help candidate countries of the time to acquire the necessary skills and experience to adopt, implement and enforce EU legislation. Twinning projects bring together public sector expertise from EU Member States and beneficiary countries with the aim of enhancing peer to peer activities. They must yield concrete mandatory operational results for the beneficiary country. Beneficiaries include candidate countries and potential candidates to EU membership, as well as countries covered by the European Neighbourhood Policy. More specifically, in the IPA region, Twinning aims to provide support for the transposition, implementation and enforcement of the EU legislation (theUnionacquis). It builds up capacities of beneficiary countries' public administrations throughout the accession process, resulting in progressive, positive developments in the region. Twinning strives to share good practices developed within the EU with beneficiary public administrations and to foster long-term relationships between administrations of existing and future EU countries. 
"Twinning Light" is designed to offer a more flexible, mid-term approach up to six months (10). Twinning light can be used to tackle any selfcontained institutional issues arising from the acquis communautaire provided the subject addressed is of limited scope, that is the structures needed to give effect to the acquis are not complex or the existing ones need little adjustment. The likeliest scenario would be implementation of a specific measure rather than reform of the general or legal framework. Twinning light projects are self-contained and cannot be used to supplement full Twinning projects, which are also self-contained and involve the obligation to deliver their own guaranteed result. Twinning light consists of the provision by the Member State of a package of services, generally involving one or more short missions (e.g. one or two weeks at a time) by selected officials, and/or, less frequently, civil servant experts staying for lengthier, intermediate periods. The financial ceiling for twinning light projects is $€ 250,000$ and their duration limited to six months; in exceptional cases this can be extended to eight months (11).

To strengthen the Ministry of Health, Public Health Institution of Turkey in the field of drinking water by means of building institutional capacity for risk assessment, early warning and management of emergency cases in line with EU Drinking Water Legislation $(98 / 83 / E C)$ EU twinning light project under the tittle of "Emergency case management and risk analysis in drinking water for the protection of public health" was taken by the Ministry of Health, Public Health Institution of Turkey.

The twinning light project was implemented within the frame of Support Activities to Strengthen the European Integration Process SEl-2009 programming with Italy for six months period between January 2013 and June 2013.
Cooperation was provided between Italy - the Istituto Superiore di Sanita, (Italian National Institute of Health - ISS), Inland Water Hygiene Section, Environmental Primary Prevention Department and Public Health Institution of Turkey, Environmental Health Department.

In the broader sense the aim of the project was to improve the drinking water sector for the protection of public health. It was expected from the project to provide improvement in the current risk assessment and emergency case management capacities of the Public Health Institution of Turkey in the field of drinking water.

\section{PROJECT IMPLEMENTATION METHODOLOGY}

The project was established on the four main targets. Result 1. Improvement of the risk assessment capacity of Public Health Institution of Turkey in drinking water. Result 2. Development of methodologies for identifying contamination in drinking water. Result 3. Improvement of the early warning capacity of the Public Health Institution of Turkey in drinking water. Result 4. Improvement of the emergency case management capacity of the Public Health Institution of Turkey in drinking water.

The methodology of the project implementation includes; current situation assessment, evaluation of the Italy applications on 98/83/EC Drinking Water Directive, working group meetings for the exchange of information and developing methodologies and procedures, in place observations by study visits, trainings, workshops, guidance documents preparation, publication and distribution, implementation of the prepared methodology in pilot province (Istanbul) and project steering committe meetings. 


\section{RESULTS}

The all project results were successfully reached.

The workshops on health risk assessment, identification of contamination and development of methodologies, early warning and management of emergency cases in drinking water were conducted with the participation of the Public Health Institution of Turkey, Ankara, İstanbul, İzmir, Çanakkale, Giresun, Samsun, Bursa, Kayseri, Gaziantep, Diyarbakır, Antalya, Balıkesir and Erzurum Public Health Directorates.

Comprehensive result oriented trainings on the developed guidance documents and the related subjects were given to the technical staffs of the Public Health Institution of Turkey, Environmental Health Department and the Public Health Directorates of the 81 Provinces.

Developing methodologies and procedures for the evaluation of short term risks and long term risks, for assessment of the control points and identification of the contamination in drinking water through microbiological and chemical quality monitoring, to manage emergency cases / crisis in drinking water with the use of EU approach, to improve the current warning system were the major subjects discussed with the core working group.

In the working group meetings the major presentations done by the Italian experts were on "European framework, trends and Italian system", “Unprecedented cyanobacterial bloom and microcystin production in a reservoir in the south of Italy: a model for emergency response and risk management", "Chemical water quality standards: indicator parameters" "Microbiological water qualty", "Prevention and security measures against potential terrorist attacks to drinking water systems in Italy", "Rapid methods for the analysis of bacterial indicators in drinking water", "Web database of procedures and methods for biological and chemical analysis of water", "Methodologies to identify the microbiological contamination in drinking water from quality monitoring data", "On line monitoring systems: a critical assessment" and "On line monitoring systems: practical experiences”, “WSPs for small water supplies in the European region", "Screening of organic chemicals for the identification of unexpected pollution", "Methodologies for the identification of chemical contamination in drinking water quality monitoring", "Harmonisation of hygienic requirements for materials and products in contact with drinking water", “Contamination from materials in contact with drinking water: Italian and European experiences", "Water safety plans in buildings".

Four guidance documents were prepared by the Italian experts, published and distributed. These documents were "Guidance on instructions for decision-making following non-compliance results in drinking water monitoring", "Guidance on identification of contamination in drinking water", "Guidance on early warning in drinking water", "Guidance on management of emergency cases / crisis in drinking water" (12 - 15).

During the project İvedik water treatment unit in Ankara and İkitelli water treatment unit in İstanbul were visited. The local visit to İstanbul was also for the methodology practices.

During the project results oriented four trainings, four workshops, one study visit and one local visit were achieved.

\section{CONCLUSION}

The technical and institutional capacity of the Ministry of Health - Public Health Institution of Turkey at the central level and the Public Health Directorates of the 81 Provinces at the provincial 
level were strengthened in the field of drinking water for risk assessment, early warning and management of emergency cases in line with EU Drinking Water Legislation $(98 / 83 / E C)$.

\section{ACKNOWLEDGEMENT}

This project was cofinanced by European Union and the Republic of Turkey. It is a twinning light partnership between Italy (Member State) and Turkey (Beneficiary).

We would like to express our deepest appreciation to all those who provided us technical and administrative assistance, expertise, knowledge, cooperation and coordination to complete this project successfully. We thank our partner Italian National Institute of Health (Istituto Superiore Di Sanita-ISS, contractor), Water Research Institute (IRSA) of the Italian National Research Council (CNR),
Studiare Sviluppo (mandated body), the Delegation of the European Union to Turkey, the Prime Ministry Undersecretariat of Treasury - Central Finance and Contracts Unit, the Ministry for EU Affairs, the Ministry of Health - Public Health Institution of Turkey - Environmental Health Department - Water Safety Unit.

We sincerely thank our Italian colleagues from ISS; Luca Lucentini (Italian project leader, Director of Inland Water Hygiene Unit, ISS), Enrico Veschetti, Emanuele Ferretti, Lucia Bonadonna, Laura Achene, Massimo Ottaviani, Federica Nigro Di Gregorio, Stefano Polesello and our Turkish collagues from Public Health Institution of Turkey - Environmental Health Department, Dr. Hüseyin IItter (Department head), Zinnet Oğuz (Unit coordinator, key expert), Alper Köşger (IT expert) and all other Water Safety Unit staff. 


\section{KAYNAKLAR}

1. Anonymous. http://ec.europa.eu/environment/ water/water-drink/index_en.html (2015).

2. Council Directive $98 / 83 /$ EC of 3 November 1998 on the quality of water intended for human consumption (OJ L 330, 5.12.1998, p.32-54).

3. Anonymous. http://ec.europa.eu/environment/ water/water-drink/legislation_en.html (2015)

4. Anonymous. http://ec.europa.eu/environment/ water/water-drink/review_en.html (2015).

5. The Commission Directive 2015/1787 of 6 October 2015 amending Annex II and III to Council Directive $98 / 83 /$ EC on the quality of water intended for human consumption (OJ L 260, 7.10.2015, p.6-17).

6. European Commission-Press release "EU introduces more efficient monitoring of drinking water for better protection of punlic health" Brussels, 28 October 2015.

7. Council Directive $2013 / 51 /$ EURATOM of 22 October 2013 laying down requirements for the protection of the health of the general public with regard to radioactive substances in water intended for human consumption (OJ L 296, 7.11.2013, p.1221).
8. The Ministry of Health, the By-law on Water Intended for Human Consumption, Official Gazette No.25730, dated 17 February 2005. The By-law amendments Official Gazettes 31.7. 2009 dated 27305 numbered, 7.03 .2013 dated 28580 numbered and 11.04.2014 dated 28969 numbered.

9. Anonymous. "Emergency case management and risk analysis in drinking water for the protection of public health" Project Fiche - SEI 2009, TR 09/IB/ EN/04-TWL, 2012. (http://www.formin.fi/public/ download.aspx?ID=79205\&GUID=\%7BAF34C2C1 4A41-4631-A440-EBD37539BFEC\%7D)

10. Anonymous. http://ec.europa.eu/enlargement/ tenders/twinning/index_en.htm 12/01/2016.

11. Anonymous. https://eufunds.gov.mt/en/EU\%20 Funds\%20Programmes/Other\%20Programmes/ Pages/Twinning-Light--Transition-Facility.aspx (2015).

12. Anonymous. "Guidance on instructions for decision-making following non-compliance results in drinking water monitoring", 2015.

13. Anonymous. "Guidance on identification of contamination in drinking water", 2015.

14. Anonymous. "Guidance on early warning in drinking water", 2015.

15. Anonymous. "Guidance on management of emergency cases/crisis in drinking water”, 2015. 